Tersedia online di: http://ejournal-balitbang.kkp.go.id/index.php/bawal
e-mail:bawal.puslitbangkan@ gmail.com
BAWAL WIDYA RISET PERIKANAN TANGKAP
Volume 10 Nomor 1 April 2018
p-ISSN: 1907-8226
e-ISSN: 2502-6410
BAWAWAL
Nomor Akreditasi: 620/AU2/P2MI-LIPI/03/2015

\title{
BIOLOGI REPRODUKSI IKAN TENGGIRI (Scomberomorus commerson Lacepede, 1800) DI PERAIRAN TELUK KWANDANG, LAUT SULAWESI
}

\section{Reproductive BIOLOGY OF Spanish Mackerel (Scomberomorus commerson Lacepede, 1800) AT KWANDANG BAY WATERS, SULAWESI SEA}

\author{
Tegoeh Noegroho*1, Thomas Hidayat ${ }^{1}$, Umi Chodriyah ${ }^{1}$ dan Mufti. P. Patria ${ }^{2}$ \\ ${ }^{1}$ Balai Riset Perikanan Laut, Cibinong, Bogor, Jl. Raya Bogor KM. 47 Cibinong, Bogor- Jawa Barat, Indonesia \\ ${ }^{2}$ Departemen Biologi FMIPA Universitas Indonesia JL. Lingkar Kampus, Pondok Cina, Depok -16424, Jawa Barat, Indonesia \\ Teregistrasi I tanggal: 17 Januari 2017; Diterima setelah perbaikan tanggal: 19 Maret 2018; \\ Disetujui terbit tanggal: 21 Maret 2018
}

\begin{abstract}
ABSTRAK
Penelitian tentang aspek biologi tenggiri di Indonesia masih jarang dilakukan, padahal upaya pemanfaatannya telah lama dilakukan oleh nelayan. Ikan tenggiri di Teluk Kwandang penangkapannya dilakukan dengan alat tangkap purse seine dan pancing ulur. Data-data terkait biologi reproduksi ikan tenggiri di perairan Kwandang belum tersedia dengan baik, oleh sebab itu perlu dilakukan kajian yang lebih lengkap. Pelabuhan Perikanan Pantai Kwandang merupakan pelabuhan baru, sehingga informasi terkait perikanan tenggiri pada khususnya sangat bermanfaat dalam pendataan dan rencana pengelolaannya. Penelitian telah dilakukan pada FebruariDesember 2012 di perairan Teluk Kwandang, Kabupaten Gorontalo Utara, dengan tujuan mengkaji aspek perikanan meliputi struktur ukuran, panjang bertama kali tertangkap dan biologi reproduksi meliputi: Tingkat Kematangan Gonad, Gonado Somatic Index (GSI), nisbah kelamin, panjang pertama kali matang gonad, diameter dan jumlah telur. Dari penelitian ini diperoleh struktur ukuran pada kisaran 25-138 cmFL, dengan rata-rata modus $60 \mathrm{cmFL}$. Panjang pertama kali tertangkap dengan purse seine dan pancing ulur masing-masing 64,7 cmFL dan 71,9 cmFL. Tingkat Kematangan Gonad ikan tenggiri didominasi oleh gonad belum matang 61,2\%, dan kondisi matang gonad 38,8\%. Puncak Gonado Somatic Index (GSI) terjadi pada bulan Mei, sehingga ikan tenggiri di Teluk Kwandang diduga memijah pada Mei-Juli. Nilai GSI mencapai puncaknya pada panjang ikan 98 $\mathrm{cmFL}$, dan akan turun pada panjang ikan lebih dari $100 \mathrm{cmFL}$. Panjang pertama kali matang gonad ikan tenggiri adalah 80,4 cmFL, pada kisaran 79,3-81,6 cmFL. Jumlah telur ikan tenggiri berkisar 417.360-9.476.520 butir pada panjang ikan 65-103 cmFL. Berdasarkan perkembangan diameter telur setiap bulan menunjukkan tipe pemijahan ikan tenggiri adalah asynchronous dengan pola pemijahan partial spawner.
\end{abstract}

Kata Kunci: Tenggiri; reproduksi; pemijahan; Teluk Kwandang

\section{ABSTRACT}

The study on biological aspects of spanish mackerel in Indonesia is uncommon, whereas the exploitation have been conducted historically. Spanish mackerel in the Kwandang Bay caught by purse seiner and handliner. The reproductive biology of mackerel fish in Kwandang waters was unavailable, therefore more study needed. Kwandang is a new port, so the information related to Spanish mackerel in particular is very useful in data collection and management plan. This research aims to assess biological aspect such as the size structure, the length at first captured and reproductive biology aspects (gonad maturity stage, Gonado Somatic Index (GSI), sex ratio, length at first maturity, number and diameter of oosit). The study was conducted in FebruaryDecember 2012 in the Kwandang Bay waters, North Gorontalo regency. The results showed that the size structure ranged between $25-138 \mathrm{cmFL}$, with average mode $60 \mathrm{cmFL}$. The length at first capture caught $(L c)$ with purse seine and handline by $64,7 \mathrm{cmFL}$ and 71,9 cmFL, respectively. The gonad maturity stage of the was dominated by 61,2\% of immature and 38,8\% of mature gonad. Gonado Somatic Index (GSI) peak was reached in May, and from this GSI value it is concluded that the Spanish mackerel spawned in May-July. The maximum 
GSI reached at $98 \mathrm{cmFL}$ and decreased at fish length exceeded $100 \mathrm{cmFL}$. Length at first maturity (Lm) of the gonad was approximately 80,4 cmFL, within the size range between 79,3-81,6 cmFL. The number of spanish mackerel oosit ranged between 417.360-9.476.520, with size ranged between 65-103 cmFL. The monthly fluctuations of oosit diameter implied that spawning type of spanish mackerel was asynchronous with partial spawner spawning pattern.

Keywords: Spanish mackerel; reproductive; spawning; Kwandang Bay

\section{PENDAHULUAN}

Tenggiri (Scomberomorus commerson) merupakan salasatu ikan ekonomis penting yang mempunyai nilai tinggi baik di pasar lokal maupun ekspor. Tenggiri adalah ikan pelagis besar yang termasuk dalam famili Scombridae (Randall, 1995). Daerah penyebaran ikan tenggiri meliputi seluruh perairan Sumatera, perairan Jawa, Nusa Tenggara, Kalimantan, Sulawesi, Maluku, dan Papua. Khusus di perairan Sulawesi meliputi perairan Teluk Palu, perairan Sulawesi Utara, dan sepanjang perairan pantai (Baskoro et al., 2004).

Tenggiri di perairan Kwandang ditangkap dengan alat tangkap purse seine (pajeko lampu) dan pancing ulur. Tenggiri di Kwandang penangkapannya dilakukan oleh kapal-kapal tradisional dibawah 10 GT. Komposisi hasil tangkapan purse seine di Kwandang adalah tenggiri, kembung, selar, layang, lemuru, cakalang, selar hijau, alualu, kuwe, peperek, sunglir, bawal, dan baronang (Noegroho et al., 2012). Seiring penangkapan yang semakin intensif dan terus menerus dikawatirkan akan mengancam kelestarian tenggiri, oleh karena itu penelitian terkait biologi reproduksi dan pemijahan tenggiri sangat penting untuk dilakukan.

Penelitian tentang biologi reproduksi ikan tenggiri (Scomberomorus commerson) di Indonesia masih jarang dilakukan. Beberapa penelitian yang pernah dilakukan di diluar perairan Indonesia antara lain: di perairan pantai Oman oleh Claereboudt et al. (2005), di perairan pantai Iran oleh Sadeghi et al. (2009), di Teluk Persia dan Laut Oman oleh Kaymaram et al. (2010), di perairan Teluk Arab bagian selatan oleh Grandcourt et al. (2005), dan di Laut India oleh Rohit \& Abdussamad, (2013), sedangkan penelitian tentang sebaran ukuran panjang dan komposisi hasil tangkapan pernah dilakukan oleh Widodo et al. (2011) di perairan Cilacap Samudera Hindia, dan Noegroho et al. (2013) di Teluk Kwandang.

Statistik produksi di Pelabuhan Perikanan Pantai (PPP) Kwandang menunjukkan perkembangan yang berfluktuasi. Berdasarkan informasi dari pengumpul ikan, tenggiri yang tertangkap di Teluk Kwandang dipasarkan ke Makasar, Manado, Jakarta dan Singapura. Produksi ikan tenggiri di PPP Kwandang sangat berfluktuasi. Total produksi ikan tenggiri di PPP Kwandang pada 2011 sebesar $10.674 \mathrm{~kg}$, pada 2012 naik $57,6 \%$ menjadi $24.664,4 \mathrm{~kg}$.
Pelabuhan Perikanan Pantai Kwandang adalah pelabuhan perikanan yang masih baru. Status pengelolaannya dari Kabupaten Gorontalo Utara diserahkan ke Dirjen Tangkap Kementerian Kelautan dan Perikanan pada 16 Desember 2010. Pembangunan pelabuhan baru selesai pada tahun 2010 akhir, sehingga praktis pencatatan data-data baru mulai pada 2011. PPP Kwandang dengan umur yang relatif muda tentunya datadata terkait biologi dan penangkapan masih sedikit tersedia, oleh sebab itu perlu dilakukan penelitian awal untuk mengetahui status sumberdaya ikan tenggiri di Teluk Kwandang. Selain itu data terkait perikanan tenggiri sangat bermanfaat dalam pengelolaan perikanan yang berkelanjutan.

Ikan tenggiri di perairan Kwandang merupakan target utama tangkapan dari purse seine dan pancing ulur. Penangkapannya masih dilakukan di perairan dalam teluk, tidak jauh dari pelabuhan, sehingga yang tertangkap kadang ikan-ikan yang masih berukuran kecil. Bila hal ini berlangsung terus-menerus dikawatirkan akan terjadi penurunan stok ikan tenggiri, oleh karena itu perlu dilakukan penelitian terhadap faktor-faktor terkait seperti biologi, penangkapan dan reproduksi.

Tujuan penelitian ini adalah untuk menganalisis aspekaspek biologi reproduksi meliputi: struktur ukuran, panjang pertama kali tertangkap, Tingkat Kematangan Gonad, Gonado Somatic Index (GSI), nisbah kelamin, panjang pertama kali matang gonad, jumlah dan diameter telur. Dari penelitian ini diharapkan dapat diperoleh informasi tentang pola reproduksi, musim dan tipe pemijahan tenggiri di Teluk Kwandang.

\section{BAHANDANMETODE Waktu dan Lokasi Penelitian}

Penelitian ikan tenggiri (Scomberomorus commerson) dilakukan pada Februari-Desember 2012. Pengumpulan data dan sampel di lakukan setiap bulan oleh penulis dibantu dengan enumerator di Pelabuhan Perikanan Pantai, Kwandang, Gorontalo Utara. Data yang dikumpulkan antara lain: panjang ikan, tingkat kematangan gonad, berat gonad, sampel gonad untuk fekunditas dan diameter telur. Lokasi penelitian tersaji pada Gambar 1. 


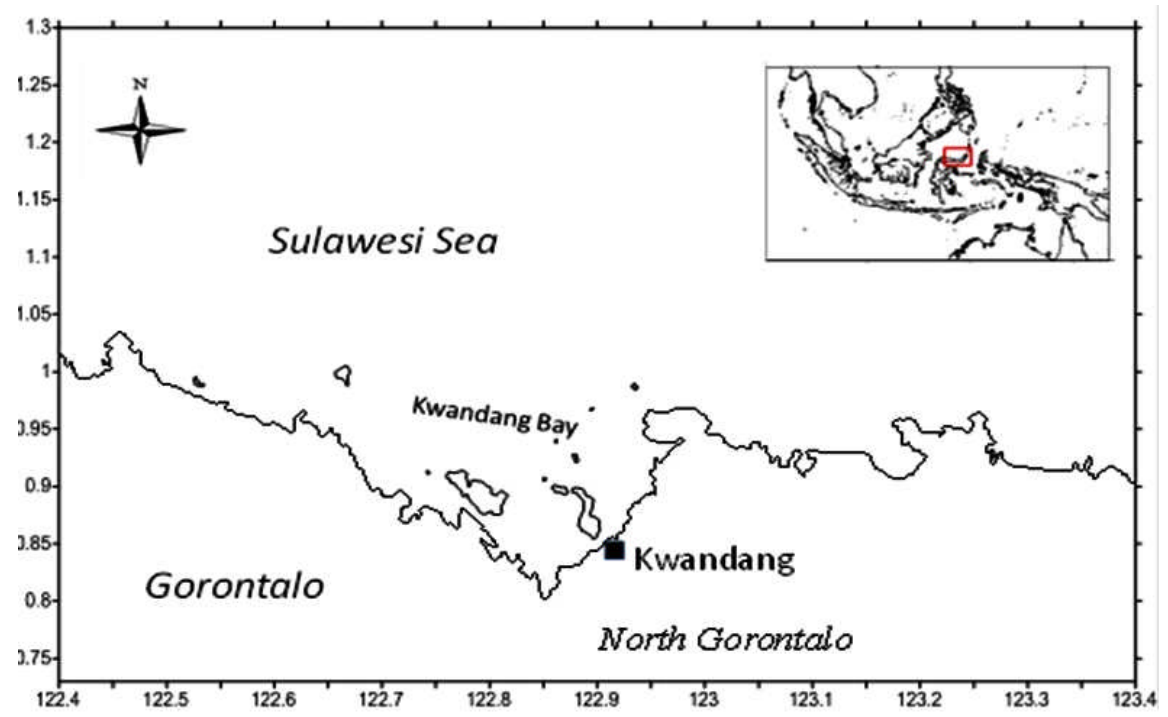

Gambar 1. Peta menunjukan lokasi penelitian di Teluk Kwandang.

Figure 1. Map showing sampling location at Kwandang Bay.

\section{Struktur Ukuran}

Data panjang ikan tenggiri diperoleh dari tempat pendaratan ikan dan pengumpul ikan. Ikan tenggiri yang di ukur adalah hasil tangkapan purse seine dan handline (pancing ulur). Panjang yang diukur adalah panjang cagak, yaitu panjang yang diukur dari ujung mulut sampai titik tengah cagak ekor. Panjang cagak diukur dengan jangka sorong (caliper) dengan panjang $150 \mathrm{~cm}$ dan ketelitian 0,1 . Dari hasil ukuran panjang ikan kemudian dibuat frekuensi panjang untuk melihat struktur ukuran ikan tenggiri.

\section{Panjang Pertama Kali Tertangkap (Lc)}

Pendugaan panjang pertama kali tertangkap dilakukan dengan membuat grafik hubungan antara distribusi panjang kelas (sumbu $\mathrm{X}$ ) dengan jumlah ikan yang dinyatakan dengan distribusi normal kumulatif estimasi (sumbu Y). Untuk memperoleh nilai Lc (length at first capture) yaitu dengan menarik garis hubungan antara sumbu X dan sumbu Y untuk nilai 50\% menurut Beverton \& Holt (1957) dalam Sparre \& Venema (1992):

$$
\text { Pr oporsi tertahan }=\frac{N}{\text { Jumlah Total }}
$$

dimana;

$\mathrm{N}=\quad$ jumlah ikan pada tiap tengah kelas (ekor)

$\mathrm{X}$ dan $\mathrm{Y}$ digunakan untuk menghitung nilai a (intercept) dan b (slope).

Menurut Sparre dan Venema (1999), untuk membuat kurva tersebut terlebih dahulu harus menghitung nilai dari SL estimasi, dengan rumus:

$$
\begin{aligned}
& \text { SLobs }=\frac{1}{1+\exp (S 1-S 2 x L)} \\
& 1+\exp \left(S_{1}-S_{2} x L\right)=\frac{1}{S L o b s} \\
& \exp \left(S_{1}-S_{2} x L\right)=\frac{1}{S L o b s}-1 \\
& \operatorname{Ln}\left[\frac{1}{S L o b s}-1\right]=S 1-S 2 x L
\end{aligned}
$$

Rumus untuk menghitung Lc adalah sebagai berikut:

$$
L 50 \%=\frac{S_{1}}{S_{2}}=L c
$$

dimana;

SLobs = Frekuensi kumulatif dari proporsi tertahan

$\mathrm{L} 50 \%=$ panjang tubuh ikan dimana $50 \%$ dari tenggiri tertahan

$\mathrm{S}_{1} \& \mathrm{~S}_{2}=$ konstanta pada rumus kurva logistik berbasis panjang

$\mathrm{S}_{1}=$ nilai intersep a (perpotongan antara garis linear dengan sumbu y)

$\mathrm{S}_{2} \quad=$ nilai slope $\mathrm{b}$ (sudut kemiringan garis regresi)

\section{Tingkat Kematangan Gonad}

Pengamatan tingkat kematangan gonad secara visual mengacu pada Schaefer \& Orange (1956), yang membagi tingkat kematangan gonad betina dan jantan menjadi 5 tingkat (Lampiran 1). Sampel gonad diperoleh dengan membeli ikan tenggiri segar. Harga Ikan tenggiri berkisar antara Rp. 40.000-Rp. 60.000. Total jumlah sampel yang diperoleh sebanyak 414 ekor, dengan kisaran panjang 27 $\mathrm{cm}-120 \mathrm{~cm}$ atau pada kisaran berat 200 gram sampai 1500 
gram. Mengingat harga sampel yang relatif mahal, jumlah sampel yang diperoleh sudah termasuk banyak, untuk melihat kondisi gonad dibutuhkan sampel ikan minimal berat 4000 gram atau minimal pada panjang $80 \mathrm{~cm}$.

\section{Gonado Somatic Index}

Gonado Somatic Index dianalisis dengan rumus yang dikemukakan oleh Effendi, (2002), sebagai berikut:

$\mathrm{GSI}=\mathrm{Wg} / \mathrm{W} \times 100 \%$

dimana: GSI = Gonado Somatic Index, $\mathrm{Wg}=$ berat gonad (gram), W = Somatic weight= berat tubuh ikan dikurangi berat gonad.

\section{Rata-rata Panjang Pertama Kali Matang Gonad (Lm)}

Nilai Lm dianalisis dengan metode Spearman-Karber dalam Udupa, (1986) yaitu sebagai berikut:

$\mathrm{m}=\mathrm{Xk}+\mathrm{X} / 2-(\mathrm{X} \mathrm{x}$ Ó pi $)$

dimana: $\mathrm{m}=$ logaritma ukuran pertama kali matang gonad, $\mathrm{Xk}=$ logaritma nilai tengah kelas terakhir dimana $100 \%$ matang gonad, $\mathrm{X}=$ selisih logaritma nilai tengah, pi= proporsi ikan matang gonad pada kelas ke-i, CL = Confident limit (batas atas dan bawah), $\mathrm{m}=$ panjang ikan pertama kali matang gonad, ni = jumlah ikan pada kelas panjang ke-i, $\quad$ qi $=1-$ pi

$\mathrm{CL}=\operatorname{Antilog}\left(\mathrm{m} \pm 1,96 \sqrt{\mathrm{X}^{2}\left(\frac{\sum \mathrm{pi} \times \mathrm{qi}}{\mathrm{ni}-1}\right)}\right)$

\section{Nisbah Kelamin (Sex Ratio)}

Nisbah kelamin dianalisis dengan membandingkan jumlah ikan jantan dan betina sesuai metode yang dikemukakan Effendi (1997), yaitu:

$\mathrm{X}=\mathrm{M} / \mathrm{F}$.

dimana: $\mathrm{X}=$ nisbah kelamin (sex ratio), $\mathrm{M}=$ jumlah ikan jantan (ekor), $\mathrm{F}=$ jumlah ikan betina (ekor)

Menurut Sugiyono (2004) untuk melihat indikator kemampuan suatu populasi dalam mempertahankan jenisnya maka nisbah kelamin harus diuji dengan uji chikuadrat/ chi-square test.

\section{Fekunditas}

Jumlah telur dihitung dengan metode gravimetri, yaitu dengan cara menghitung beberapa bagian dari sampel gonad yang diberi larutan gilson. Fekunditas dianalisis dengan rumus yang dikemukakan oleh Effendi (1979) yaitu:

$\mathrm{F}=\mathrm{G} / \mathrm{g} \times \mathrm{N}$

dimana: $\mathrm{F}=$ fekunditas (butir), $\mathrm{G}=$ berat total telur (gram), $\mathrm{g}=$ berat telur contoh gram), $\mathrm{N}=$ jumlah telur pada contoh (butir).

\section{Diameter Telur}

Diameter telur diukur dengan mikrometer berskala yang sudah ditera. Pembagian kelompok diameter telur dibuat pada interval kelas $0,05 \mathrm{~mm}$ sesuai yang disampaikan Devaraj (1983).

\section{HASIL DAN BAHASAN \\ Hasil}

\section{Struktur Ukuran}

Dari bulan Februari sampai Desember diperoleh sampel ukuran panjang ikan sebanyak 5.248 ekor. Kisaran panjang yang diperoleh antara 25-138 cmFL (Tabel 1). Panjang terkecil dan terbesar keduanya ditemukan pada bulan Juni. Kisaran modus terbesar pada bulan Maret dan Agustus, yaitu $85-90 \mathrm{~cm}$, sedangkan terkecil pada September, yaitu antara $43-48 \mathrm{~cm}$. Sebaran frekuensi panjang bulanan ikan tenggiri dapat dilihat pada Lampiran 2.

\section{Rata-rata Panjang Pertama Kali Tertangkap (Length at First Capture)}

Perhitungan panjang pertama kali tertangkap ikan tenggiri yang tertangkap dengan purse seine adalah 64,7 $\mathrm{cm}$, sedangkan yang tertangkap dengan pancing ulur adalah $71,9 \mathrm{~cm}$. Kurva sigmoid dari panjang pertama kali tertangkap ikan tenggiri tersaji pada Gambar 2.

\section{Tingkat Kematangan Gonad}

Dari 414 ekor sampel ikan tenggiri, diketahui kondisi gonad matang (TKG IV) ditemukan hampir setiap bulannya (Gambar 3), sedangkan kondisi gonad yang belum matang (TKG I dan II) banyak juga ditemukan setiap bulannya. 
Tabel 1. Frekuensi panjang ikan tenggiri pada Februrari-Desember 2012

Table 1. $\quad$ Length frequency of Spanish mackerel on February-December 2012

\begin{tabular}{lccc}
\hline \multirow{2}{*}{ Bulan/Month } & n & \multicolumn{2}{c}{ Kisaran Panjang/Size Range $(\mathbf{c m})$} \\
\cline { 3 - 4 } & & Kisaran/Range & Modus/Mode \\
\hline Februari & 211 & $39-107$ & $49-54$ \\
\hline Maret & 155 & $42-115$ & $85-90$ \\
\hline April & 229 & $40-115$ & $49-54$ \\
\hline Mei & 342 & $42-110$ & $55-60$ \\
\hline Juni & 1062 & $27-110$ & $61-66$ \\
\hline Juli & 893 & $25-138$ & $55-60$ \\
\hline Agustus & 604 & $29-122$ & $85-90$ \\
\hline September & 688 & $37-107$ & $43-48$ \\
\hline Oktober & 195 & $36-131$ & $49-54$ \\
\hline November & 478 & $41-114$ & $55-60$ \\
\hline Desember & 391 & $34-119$ & $61-66$ \\
\hline
\end{tabular}

(Sumber:Hasil pengolahan data primer)
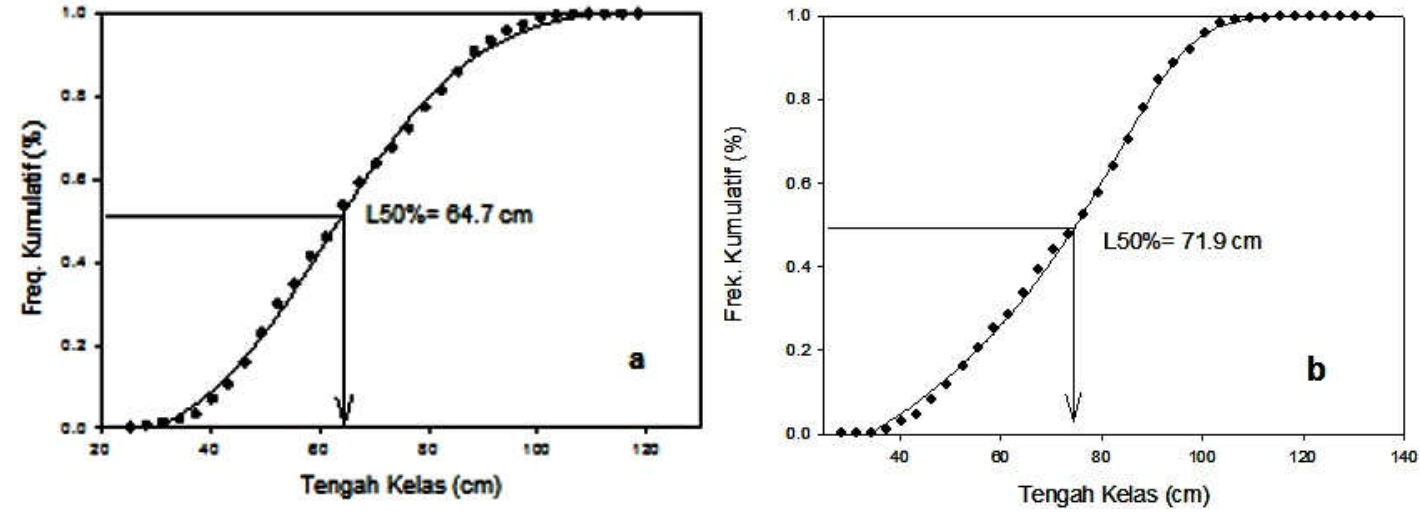

Gambar2. Panjang pertama kali tertangkap ikan tenggiri yang tertangkap dengan purse seine (a), dan tertangkap dengan pancing ulur (b).

Figure 2. The length at first capture of spanish mackerel caught by purse seine (a), and by handline(b).

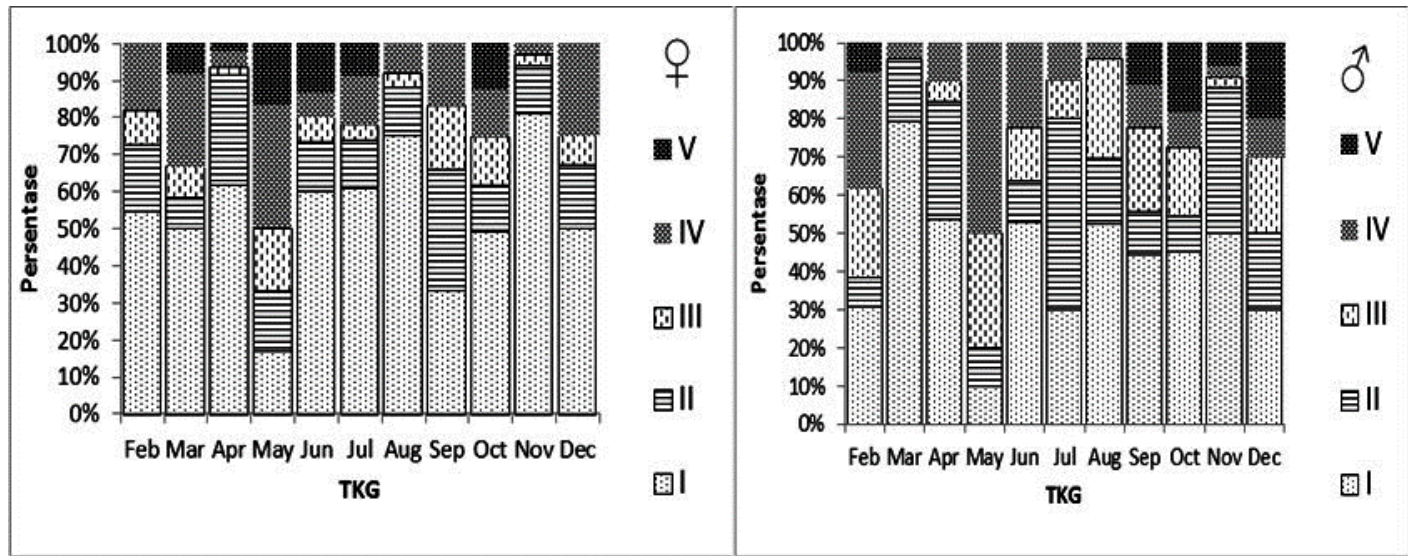

Gambar 3. Tingkat kematangan gonad tenggiri.

Figure 3. Maturity stages of spanish mackerel. 


\section{Gonado Somatic Index (GSI)}

Dari hasil perhitungan nilai GSI ikan tenggiri diperoleh kisaran 0,23-4,81 untuk tenggiri betina, dengan rata-rata 1,59; sedangkan tenggiri jantan nilai GSI berkisar 0,294,24 , dengan rata-rata 1,47 . Nilai GSI tertinggi pada bulan Mei dan Desember (Gambar 4). Naiknya nilai GSI pada bulan Mei menunjukkan kondisi gonad telah berkembang semakin besar, sehingga dapat diduga setelah puncak GSI

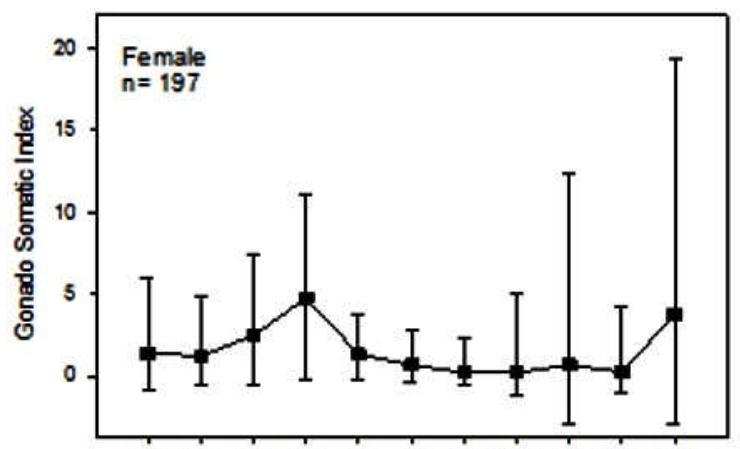

Feo Mar Apr May Jun Jul Aug Sep oct Nov Dec Month pada bulan Mei, ikan tenggiri akan memijah. Nilai GSI juga berubah sesuai dengan Tingkat Kematangan Gonad seperti yang terlihat pada Tabel 2 .

Nilai GSI bertambah seiring dengan membesarnya ukuran gonad ikan. Pada Gambar 5, garis parabola menunjukkan nilai GSI naik sampai panjang $98 \mathrm{~cm}$, kemudian turun panjang $>100 \mathrm{~cm}$.

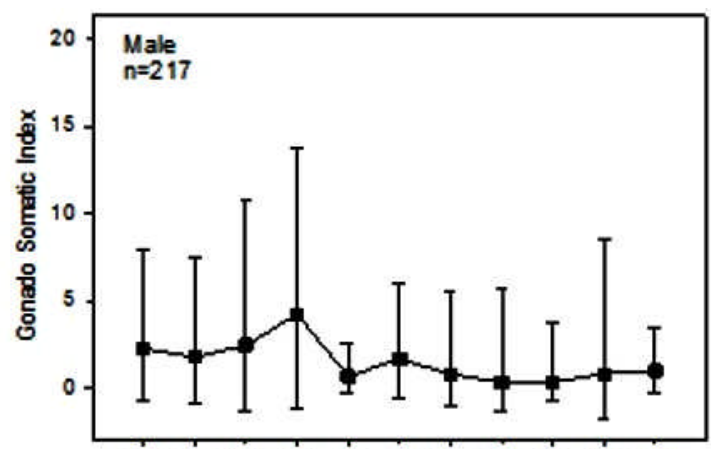

Feb Mar Apr May Jun Jul Aug Sep Oct Nov Dec Month

Gambar4. Gonado somatic indek tenggiri.

Figure 4. Gonado somatic index of spanish mackerel.

Tabel 2. Hubungan nilai GSI dan tingkat kematangan gonad

Table 2. The Relationship of GSI and gonado maturity stages

\begin{tabular}{cccc}
\hline \multirow{2}{*}{ Kelamin/ Sex } & TKG/ Maturity Stage & \multicolumn{2}{c}{ Gonado Somatic Index } \\
& Kisaran/ Range & Rata-Rata/ Average \\
\hline Betina/ Female & I & $0,008-0,659$ & 0,138 \\
& II & $0,174-1,042$ & 0,409 \\
& III & $1,026-2,030$ & 1,492 \\
& IV & $2,364-6,423$ & 3,856 \\
Jantan/ Male & V & $1,868-3,729$ & 2,409 \\
& I & $0,011-1,095$ & 0,145 \\
& II & $0,050-1,971$ & 0,810 \\
& III & $0,895-3,014$ & 1,602 \\
& IV & $1,823-6,669$ & 3,469 \\
& V & $1,950-5,550$ & 2,946 \\
\hline
\end{tabular}

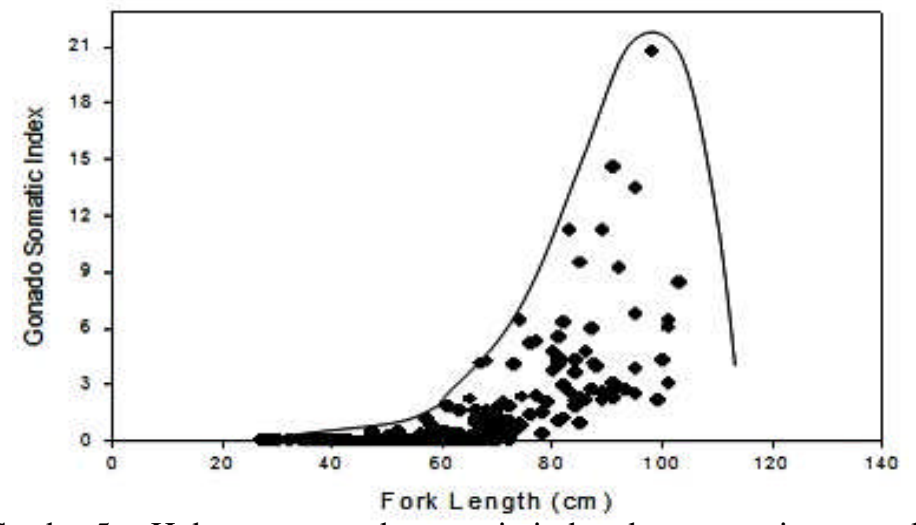

Gambar 5. Hubungan gonado somatic index dengan panjang cagak.

Figure 5. Relationship of gonado somatic index and fork length. 


\section{Nisbah Kelamin}

Dari nisbah kelamin diperoleh persentase rasio seimbang terjadi pada Agustus dan November. Rasio betina lebih banyak dari jantan terjadi pada April, Juli, dan Desember (Tabel 3). Rata-rata rasio jantan dan betina pada adalah 1,2:1. Dari uji chi square diketahui bahwa terdapat perbedaan yang nyata antara jumlah ikan tenggiri jantan dan betina (Lampiran 3).

\section{Rata-rata Panjang Pertama Kali Matang Gonad (Lm)}

Dalam perhitungan panjang pertama kali matang gonad diperoleh nilai $\mathrm{Lm}$ rata-rata $80,4 \mathrm{~cm}$, pada kisaran antara $79,3-81,6 \mathrm{~cm}$. Berdasarkan pada nilai Lm persentase tenggiri yang belum matang gonad adalah $61,2 \%$ dan yang matang gonad $38,8 \%$. Persentase kematangan gonad bulanan dapat dilihat pada Tabel 4.

Tabel 3. Nisbah kelamin ikan tenggiri

Table 3. Sex ratio of spanish mackerel

\begin{tabular}{ccc}
\hline \multirow{2}{*}{ Bulan/ Month } & \multicolumn{2}{c}{ Nisbah Kelamin/ Sex Ratio } \\
\cline { 2 - 3 } & Betina/ Female & Jantan/ Male \\
\hline Feb & 1 & 1,2 \\
Mar & 1 & 2,0 \\
Apr & 1 & 0,8 \\
May & 1 & 1,7 \\
Jun & 1 & 2,1 \\
Jul & 1 & 0,4 \\
Aug & 1 & 1,0 \\
Sep & 1 & 1,3 \\
Oct & 1 & 1,4 \\
Nov & 1 & 1,0 \\
Dec & 1 & 0,8 \\
\hline Rata-rata/ Average & 1 & 1,2 \\
\hline
\end{tabular}

Tabel 4. Kematangan gonad tenggiri setiap bulan

Table 4. Monthly gonado maturity of spanish mackerel

\begin{tabular}{ccc}
\hline \multirow{2}{*}{ Bulan/ Month } & \multicolumn{2}{c}{ Kematangan Gonad/ Gonad Maturity (\%) } \\
\cline { 2 - 3 } & Immature & Mature \\
\hline Feb & 81 & 19.0 \\
Mar & 46,5 & 53,5 \\
Apr & 51 & 49.0 \\
May & 60,8 & 39,2 \\
Jun & 71,1 & 28,9 \\
Jul & 31,9 & 68,1 \\
Aug & 48,3 & 51,7 \\
Sep & 81,1 & 18,9 \\
Oct & 54,9 & 45,1 \\
Nov & 74,5 & 25,5 \\
Dec & 72,2 & 27,9 \\
\hline Rata-ratal Average & 61,2 & 38,8 \\
\hline
\end{tabular}

\section{Fekunditas}

Dari sampel telur tenggiri diketahui jumlah telur ikan tenggiri berkisar 417.360-9.476.520 butir, dengan rata-rata 3.419 .663 butir, pada kisaran panjang antara $65-103 \mathrm{~cm}$. Hubungan panjang dengan jumlah telur memperlihatkan bahwa setiap perubahan panjang ikan tenggiri akan mempengaruhi perkembangan jumlah telurnya juga, namun pengaruh tersebut tidak signifikan yaitu hanya sebesar $30 \%$ (Gambar 6).

\section{Diameter Telur}

Dari sebaran frekuensi diameter telur diperoleh 16 kelompok ukuran sesuai pada (Lampiran 4). Pada tahap O (diameter telur 0,79-0,84 $\mathrm{mm}$ ) dan $\mathrm{P}(0,84-0,89 \mathrm{~mm})$ hanya ditemukan pada bulan Juni dan Juli, hal ini semakin menguatkan dugaan bahwa disaat musim pemijahan bulan Mei-Juli diiringi juga dengan adanya kelompok telur pada diameter yang telah siap dikeluarkan. 


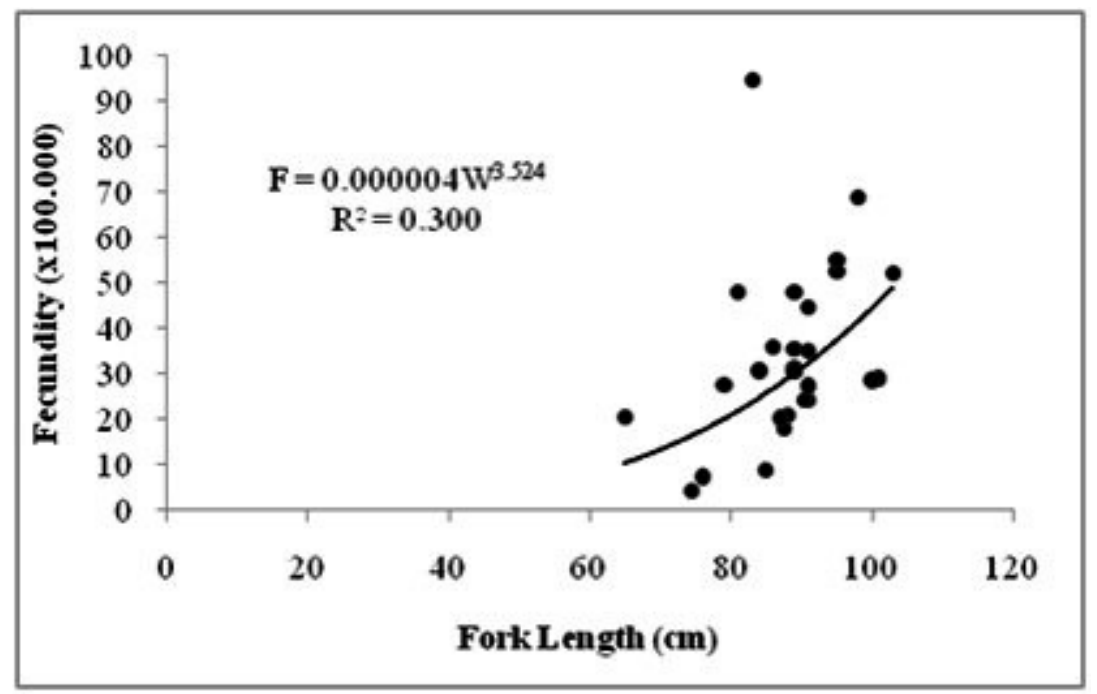

Gambar 6. Hubungan panjang cagak dengan jumlah telur.

Figure 6. Relationship of fecundity and fork length.

\section{Bahasan}

Kaymaram et al. (2010) dengan alat tangkap yang digunakan adalah gillnet di Teluk Persia dan Laut Oman.memperoleh sebaran ukuran 35-144 cm untuk ikan jantan, dan 29-154 untuk ikan betina. Claereboudt et al. (2005) memperoleh sebaran panjang 40-170 di Teluk Oman dan Laut Arab dengan alat tangkap gillnet. Perbedaan ini diduga karena penggunaan alat tangkap yang berbeda. Darvishi et al. (2011) di Teluk Persia dan Laut Oman dengan gillnet memperoleh ukuran 20-164 cm, dengan modus 79 $\mathrm{cm}$. Di Trengganu Malaysia ikan tenggiri yang didaratkan mempunyai kisaran panjang 20-103 cm (Bachok et al., 2004). Kisaran panjang yang diperoleh pada penelitian ini ukuran terkecilnya hampir sama dengan yang tertangkap di Teluk Persia, Laut Oman, Laut Arab, dan Malaysia, tetapi ukuran maksimalnya lebih kecil. Ukuran maksimal yang tertangkap di Teluk Kwandang adalah $138 \mathrm{~cm}$.

Berdasarkan panjang pertama kali matang gonad ikan tenggiri di Teluk Kwandang $(80,4 \mathrm{~cm})$ terlihat bulan Februari masih didominasi ikan yuwana yang belum matang gonad. Pada Maret dan Agustus ukuran didominasi oleh ukuran diatas nilai Lm. Pada April, Mei, Juni, dan Juli sebagian didominasi ikan-ikan yuwana dan sebagian ada ikan ukuran besar yang tertangkap. Pada September ukuran didominasikan juga oleh ikan-ikan kecil yang belum matang gonad. Pada Oktober ikan yuwana dan ukuran yang matang gonad hampir seimbang. Pada November dan Desember didominasi ikan yuwana dan sebagian kecil ikan yang matang gonad.

Sebaran frekuensi panjang ikan tenggiri memperlihatkan ukuran ikan yang belum matang gonad mendominasi hampir setiap bulan dibanding yang telah matang gonad. Hal ini bila dibiarkan terus menerus akan membahayakan populasi ikan tenggiri. Salahsatu hal yang bisa dilakukan adalah dengan memperbesar mata jaring atau mata pancing, sehingga ikan-ikan yang tertangkap ukurannya lebih besar.

Panjang pertama kali tertangkap ikan tenggiri dari purse seine masih berada di bawah nilai Lm sedang Lc pancing ulur ada yang berada di bawah nilai Lm ada juga yang di atas nilai Lm. Jayabalan et al. (2011) di Saudi Arabia, Bahrain, Qatar, UEA, Oman, dan Kuwait ikan ditangkap dengan gillnet, trolling line, dan handline adalah $63 \mathrm{~cm}$. Al-Kiyumi, (2011) di Teluk Persia, Laut Oman, dan Laut Arab mendapatkan nilai Lc $63 \mathrm{~cm}$ juga dari hasil tangkapan seluruh alat tangkap. Al-Kiyumi juga melakukan ekperimen terhadap selektifitas gillnet, dengan merubah besarnya mata jaring (mesh size) dari $110 \mathrm{~mm}-140 \mathrm{~mm}$, dan hasilnya semakin besar mata jaring maka persentase ukuran ikan kecil (juvenille) yang tertangkap semakin berkurang. Seperti yang dilakukan oleh Al-Kiyumi, alat tangkap purse seine yang dioperasikan di perairan Teluk Kwandang perlu diperbesar mata jaringnya. Govender et al. (2005) di Laut Oman dari berbagai alat tangkap seperti handline, drift gillnet, dan trolling line, memperoleh ukuran pertama tertangkap ikan tenggiri $45 \mathrm{~cm}$. Nilai Lc ikan tenggiri yang tertangkap purse seine maupun pancing ulur yang lebih kecil dari Lm mengindikasikan bahwa ukuran mata jaringnya terlalu kecil, sehingga dominan tertangkap ikan tenggiri yang belum matang gonad.

Persentase ikan yang tertangkap dan belum matang gonad lebih dominan dibandingkan ikan yang telah matang gonad, hal ini disebabkan oleh pengaruh penggunaan alat tangkap purse seinel pajeko dengan mata jaring 1 inch, dan daerah penangkapan yang terlalu dekat dengan pantai atau di dalam perairan teluk (nursery ground). Kondisi ini bila berlangsung terus menerus dapat membahayakan 
keberlanjutan stok ikan tenggiri di Teluk Kwandang. Harus ada peraturan yang mengatur penggunakaan alat tangkap di perairan sempit seperti di pantai atau teluk. Alat tangkap yang digunakan harus mempunyai selektifitas tinggi serta daerah penangkapan harus diatur diluar daerah asuhan.

Di Teluk Kwandang juvenil ikan tenggiri bayak tertangkap di perairan teluk oleh nelayan bagan apung, yang mencari ikan teri. Ikan tenggiri pada ukuran panjang $<$ dari $10 \mathrm{~cm}$ juga tertangkap di sekitar mangrove dan pelabuhan Kwandang oleh nelayan yang mencari anakan ikan kwe untuk dibesarkan di karamba. Ikan tenggiri sering ditemukan di tepi landas kontinen sampai ke perairan pantai yang dangkal, terumbu yang landai dan laguna dengan kedalaman antara 10-70 meter (McPherson 1985; Myers, 1991). Di Utara Queensland Australia yuwananya ditemukan dengan ukuran sampai $10 \mathrm{~cm}$ di anak sungai, estuari, dan perairan berlumpur (mangrove), di daerah terlindung selama musim hujan (McPherson, 1981). Pada saat dewasa ikan tenggiri cenderung soliter, sedangkan

Tabel 5. Nisbah kelamin tenggiri di beberapa lokasi Table 5. Sex ratio of spanish mackerel in several area saat muda biasa membentuk gerombolan kecil (Collette, 2001).

Kaymaram et al. (2010) melaporkan kondisi yang sama di Teluk Oman dimana hampir setiap bulan ikan tenggiri yuwana terus diperoleh kecuali Mei-Juni, TKG IV dan V banyak pada Mei-Juni sehingga Kaymaram menduga tenggiri di Teluk Oman memijah setelah Juni. Di Teluk Arab dilaporkan TKG I diperoleh hampir setiap bulan, yaitu April-Juni dan November-Desember, TKG II dan III ada setiap bulan kecuali bulan September, TKG IV dijumpai pada bulan April-Agustus, dan TKG V Juni-Januari (Grandcourt et al., 2005).

Dari uji chi square diketahui terdapat perbedaan yang nyata antara jumlah tenggiri jantan dan betina. Hal ini mengindikasikan bahwa dalam proses pemijahan ikan tenggiri, proses pembuahan sel telur oleh sel gamet bisa terjadi dalam rasio jantan yang lebih banyak maupun seimbang. Nisbah kelamin tenggiri di beberapa lokasi dapat dilihat pada Tabel 5.

\begin{tabular}{lccl}
\hline \multicolumn{1}{c}{ Lokasi/ Area } & \multicolumn{2}{c}{ Nisbah Kelamin/ Sex Ratio } & \multicolumn{1}{c}{ Referensi/ Reference } \\
& Jantan/ Male & Betina/ Female & \\
\hline Perairan Peninsula, India & 1,2 & 1 & Devaraj (1983) \\
Perairan Pantai Oman & 0,74 & 1 & Claereboudt et al. (2005) \\
Pantai Barat Australia & 1 & 1,2 & Mackie et al. (2005) \\
Teluk Persia dan Laut Oman & 0,97 & 1 & Kaymaram et al ( (2010) \\
Teluk Kwandang Laut Sulawesi & 1,2 & 1 & Penelitian ini/Fhis study \\
\hline
\end{tabular}

Dari nisbah kelamin menunjukkan bahwa ikan jantan lebih banyak daripada ikan betina. Nisbah kelamin pada bulan Juni, dimana diduga ikan tenggiri memijah menunjukkan jumlah ikan tenggiri jantan lebih banyak dibanding ikan betina. Hal ini mengindikasikan bahwa dalam proses pemijahan ikan tenggiri, proses pembuahan sel telur oleh sel gamet bisa terjadi dalam rasio jantan yang lebih banyak. Ikan tenggiri yang mempunyai tipe perkembangan oosit asynchronous bisa beberapa kali mengeluarkan telur dalam waktu tertentu dan tempat yang berbeda, sehingga pembuahan bisa terjadi beberapa kali di tempat yang berbeda oleh ikan tenggiri jantan lainnya. Keberlanjutan stok ikan tenggiri sangat dipengaruhi oleh keberhasilan populasi ikan tenggiri untuk dapat bereproduksi dengan baik. Dalam bereproduksi dengan baik ikan tenggiri membutuhkan kondisi perairan yang sesuai, pasangan, lokasi yang cocok, ketersediaan makanan, dan lain sebagainya. Kegiatan perikanan khususnya penangkapan yang sangat berpengaruh harus diatur agar keseimbangan populasi ikan tenggiri lebih terjaga.

Masing-masing lokasi mempunyai nisbah kelamin yang berbeda antara betina dan jantan seiring berubahnya kelompok ukuran yang diamati (Mackie et al., 2005). Variasi dalam nisbah kelamin sering terjadi dikarenakan 3 faktor, yaitu perbedaan tingkah laku reproduksi, kondisi lingkungan, dan penangkapan (Bal \& Rao, 1984).

Pemijahan ikan tenggiri terjadi satu bulan atau lebih setelah nilai GSI tertinggi. Dari fluktuasi nilai GSI bulanan dapat diketahui tenggiri di Teluk Kwandang memijah pada Mei-Juli. Pada bulan Januari tidak bisa disimpulkan ada pemijahan disebabkan karena data bulan Januari tidak tersedia. Musim pemijahan tenggiri di beberapa lokasi lain tersaji pada Tabel 6. Selain dipengaruhi oleh faktor internal yaitu perkembangan gonad di dalam tubuh ikan, pemijahan juga dipengaruhi faktor eksternal yaitu kondisi lingkungan, dan ketersediaan makan. Ikan tenggiri betina mempunyai nilai GSI rata-rata lebih besar dibanding ikan jantan. GSI berubah sesuai dengan Tingkat Kematangan Gonad ikan tenggiri.

Nilai GSI terus bertambah mulai dari TKG I sampai TKG IV, kemudian mulai turun pada TKG V yang disebabkan karena telah memijah. GSI turun pada panjang lebih dari $98 \mathrm{~cm}$ yang mengindikasikan berat gonad tenggiri telah berkurang karena memijah. Claereboudt et al., (2005) 
melaporkan nilai GSI ikan tenggiri di Laut Oman bertambah seiring bertambahnya ukuran panjang sampai $110 \mathrm{~cm}$, dan kemudian turun lagi pada ukurann ikan yang lebih panjang.

Nilai GSI bertambah seiring dengan bertambahnya ukuran panjang ikan sampai ukuran tertentu. Pada Gambar 5, garis parabola menunjukkan nilai GSI naik sampai pada ukuran $98 \mathrm{~cm}$, kemudian turun pada ukuran yang lebih panjang (99-102 cm). GSI turun pada ukuran ikan yang lebih panjang dari $98 \mathrm{~cm}$ mengindikasikan bahwa ikan pada ukuran yang lebih besar telah mengeluarkan sebagian gonadnya. Hal ini dapat juga diartikan bahwa

Tabel 6. Musim pemijahan tenggiri di beberapa lokasi Table 6. $\quad$ Spawning season of spanish mackerel at several area

\begin{tabular}{lll}
\hline \multicolumn{1}{c}{ Lokasi/ Area } & Musim Pemijahan/ Spawning Season & \multicolumn{1}{c}{ Referensi/ Reference } \\
\hline Pantai Selatan India & Januari, September-Oktober & Devaraj (1983) \\
Laut Merah dan Teluk Persia & Maret-Juni & Kedidi \& Abususha (1987) \\
Perairan Queensland-Australia & Oktober-November & McPherson (1993) \\
Perairan Saudi Arabia & Maret-Juni & Abdulqader et al. (2001) \\
Teluk Oman & Maret-Juli & Abdulqader et al. $(2001)$ \\
Laut Oman & Februari, Mei-Juni & Al-Oufi et al. (2004) \\
Teluk Arab & April-Agustus & Grandcourt et al. (2005) \\
Teluk Oman & Mei-Juni & Claereboudt et al. $(2005)$ \\
Perairan Pantai Iran & Maret, Agustus, September & Sadeghi et al. (2009) \\
Teluk Persia dan Laut Oman & Juni-September & Kaymaram et al. (2010) \\
Teluk Kwandang Laut Sulawesi & Mei-Juli & Penelitian ini/ Fhis study \\
\hline
\end{tabular}

Bila nilai Lm yang diperoleh semakin kecil menunjukkan pertumbuhan ikan yang lambat karena kondisi lingkungan yang kurang sesuai. Kondisi lingkungan yang kurang sesuai salah satunya disebabkan kurang bagusnya kualitas air dan minimnya ketersediaan pakan alami ikan. Alat tangkap pancing ulur lebih direkomendasikan daripada purse seine untuk dioperasikan di perairan Teluk Kwandang. Bila tidak dilakukan pengaturan dan

pengawasan terhadap kegiatan penangkapan maka sumberdaya tenggiri bisa terancam kelestariannya. Bila tenggiri yang tertangkap dibawah nilai Lm itu berarti ikan tersebut belum melakukan pemijahan. Agar rekrutmen lebih terjaga maka panjang tenggiri yang ditangkap harus lebih dari nilai Lm $(80,4 \mathrm{~cm})$. Nilai Lm dari beberapa lokasi tersebut bisa dilihat pada Tabel 7. pertumbuhan setiap individu ikan berbeda-beda, termasuk perkembangan gonadnya, sehingga walaupun ukuran panjangnya sama belum tentu nilai GSI nya sama. Ikan dengan ukuran lebih panjang bisa mempunyai nilai GSI yang lebih besar bisa pula mempunyai nilai GSI yang lebih kecil (perhatikan Gambar 5). Claereboudt et al. (2005) melaporkan hasil bahwa nilai GSI ikan tenggiri di Oman bertambah seiring bertambahnya panjang ikan sampai 110 $\mathrm{cm}$, kemudian nilai GSI justru turun pada ukuran ikan yang lebih panjang, sedangkan pada panjang 50-70 cm nilai GSI bertambah perlahan seiring berubahnya ukuran panjang.

Tabel 7. Panjang pertama kali matang gonad tenggiri

Table 7. Length at first maturity of spanish mackerel

\begin{tabular}{|c|c|c|c|c|}
\hline \multirow[b]{2}{*}{ Lokasi/ Area } & \multicolumn{3}{|c|}{ Nilai Lm/ Lm Value } & \multirow[b]{2}{*}{ Referensi/ Reference } \\
\hline & $\begin{array}{l}\text { Betina/ } \\
\text { Female }\end{array}$ & $\begin{array}{l}\text { Jantan/ } \\
\text { Male }\end{array}$ & $\begin{array}{l}\text { Gabungan/ } \\
\text { Combination }\end{array}$ & \\
\hline Pantai Barat Australia & 80,9 & 62 & & Mackie et al. (2004) \\
\hline Laut Arab & 70,7 & 76,1 & & Claereboudt et al. (2005) \\
\hline Teluk Oman & 80,7 & 84,6 & & Claereboudt et al. (2005) \\
\hline Teluk Persia dan Laut Oman & 83,6 & & & Kaymaran et al. (2008) \\
\hline Teluk Arab Selatan & 86,3 & 72,8 & & Grandcourt et al. (2005) \\
\hline Semenanjung Peninsula, India & & & $70,1-80$ & Devaraj (1983) \\
\hline Madagaskar, Papua New & & & & Collete \& Russo (1979); \\
\hline Guinea,Australia Tenggara & & & $70-80$ & McPherson (1993) \\
\hline Afrika Selatan & & & $90-105$ & Govender (1994) \\
\hline Pantai Iranian, Teluk Persia, Oman & & & 83,6 & Darvishi et al., (2011) \\
\hline Teluk Kwandang, Laut Sulawesi & & & 80,4 & Penelitian ini/Fhis study \\
\hline
\end{tabular}


Hubungan jumlah telur dengan panjang menunjukkan nilai $\mathrm{R}^{2}$ kecil, berarti adanya hubungan yang kurang kuat antara panjang dengan jumlah telur tenggiri. Rendahnya nilai korelasi juga menunjukkan bervariasinya jumlah telur pada ukuran panjang yang sama (Batts, 1972 dalam Effendi, 1979). Mackie et al. (2003) melaporkan jumlah telur tenggiri di Australia Barat berkisar antara 320.000-950.000 butir, tenggiri betina dengan berat $10 \mathrm{~kg}$ mempunyai fekunditas rata-rata 750.000 butir dengan potensi reproduksi mencapai 30 juta telur dalam satu musim pemijahan. Mackie juga menjelaskan bahwa tenggiri betina memijah setiap tiga hari atau selama puncak periode pemijahan dan berlangsung dalam durasi 4 bulan. Sedangkan Siddeek (1995) di Samudera Hindia bagian barat melaporkan fekunditas tenggiri antara 590.0001.500 .000 butir. Fekunditas tenggiri berbeda-beda pada tiap lokasi dipengaruhi oleh komposisi umur, faktor lingkungan seperti ketersediaan makanan, kepadatan populasi, suhu perairan, dan oksigen terlarut. Perbedaan jumlah telur juga bisa diartikan adanya perbedaan ras (Effendi, 2002).

Dari perkembangan diameter telur setiap bulan memperlihatkan tipe pemijahan tenggiri asynchronous, yaitu oosit dari setiap tahap perkembangan diameter telur tidak ditandai dengan kelompok yang dominan (Murua \& Kraus, 2003). Saat proses pematangan telur terjadi baru terlihat beberapa kelompok ukuran. Ada beberapa puncak perkembangan diameter telur pada kondisi matang diiringi juga dengan perkembangan telur yang belum matang menandakan bahwa tenggiri di Teluk Kwandang memiliki masa pemijahan yang relatif panjang.

Pola pemijahan ikan tenggiri berdasarkan diameter telur adalah partial spawner, yaitu ikan yang memijahkan telurnya tidak sekaligus dalam satu musim pemijahan (Lowe-McConnell, 1991). Telur yang sudah matang dan siap untuk dipijahkan pada waktu dan tempat yang sesuai maka akan dikeluarkan lebih dulu. Kemudian kelompok diameter yang belum matang akan terus berkembang sampai matang dan akan dikeluarkan pada waktu dan tempat yang sesuai.

\section{KESIMPULAN}

Struktur ukuran ikan tenggiri (Scomberomorus commerson) yang tertangkap diperairan Teluk Kwandang didominasi oleh ikan muda (juvenille). Penggunaan purse seine dengan mata jaring 1 inch menyebabkan ukuran panjang ikan tenggiri yang tertangkap kecil, masih dibawah nilai Lm. Tingkat Kematangan Gonad ikan tenggiri yang tertangkap di Teluk Kwandang didominasi oleh gonad ikan yang belum matang gonad. Musim pemijahan ikan tenggiri di Teluk Kwandang berlangsung pada Mei-Juli. Terdapat perbedaan yang nyata antara jumlah tenggiri jantan dan betina, hal ini berarti proses pembuahan sel telur oleh sel sperma bisa berlangsung pada kondisi jumlah ikan jantan lebih banyak. Panjang pertama kali matang gonad ikan tenggiri adalah 80,4 cmFL atau pada kisaran antara 79,3$81,6 \mathrm{cmFL}$. Ikan tenggiri di Teluk Kwandang mempunyai jumlah telur yang berkisar antara 417.360-9.476.520 butir. Tipe pemijahan ikan tenggiri bila dilihat dari perkembangan oositnya adalah asynchronous, dengan pola pemijahan partial spawner.

\section{PERSANTUNAN}

Tulisan ini adalah merupakan hasil kegiatan Penelitian Indek Kelimpahan Ikan Pelagis Besar di Laut Sulawesi dan Laut Jawa Tahun 2012. Terimakasih kepada Prof. Dr. Ali Suman dan Dr. I Gede Sedana Merta atas segala arahannya, serta seluruh peneliti Balai Penelitian Perikanan Laut atas segala dukungannya, enumerator di Kwandang: Arsila Dude, Dinas Kelautan dan Perikanan Gorontalo Utara, serta Kepala PPP Kwandang: Ibrahim, A.Pi, atas segala bantuannya saat kegiatan penelitian di Kwandang.

\section{DAFTAR PUSTAKA}

Al-Kiyumi, (2011). Status of share stock fishery of kingfish (Scomberomorus commerson). FAO workshop on the status of share fisheries resources in the northern Arabian Sea, Iran, Oman, and Pakistan. FAO Fisheries and Aquaculture Report. p. 20-26.

Bachok, Z., M. I. Mansor., \& R. M. Noordin. (2004). Diet composition and food habits of demersal and pelagic marine fi shes from Terengganu waters, east coasto $\mathrm{f}$ Peninsular Malaysia. NAGA, World Fish Center Quarterly, 27(3).

Bal, D. V. \& Rao, K. V. (1984). Marine Fisheries (p. 24). Tata Mc. Graw-Hill Publishing Company Limited, New Delhi.

Baskoro, M., Ronny I. Wahyu., \& Effendi, A. (2004). Migrasi dan distribusi ikan. Jurusan pemanfaatan sumberdaya perikanan (p. 22). Fakultas Perikanan dan Ilmu Kelautan, Institut Pertanian Bogor.

Claereboudt, M. R., McIlwain, J. L., Al-Oufi, H. S., \& AbuAli, A. A. (2005). Patterns of reproduction and spawning of the kingfish (Scomberomorus commerson, Lacepede) in the coastal waters of the Sultanate of Oman. Fisheries Research, 73, 273-282.

Darvishi, M., Kaymaram, F., Salarpouri, A., Behzadi, S., \& Daghooghi, B. (2011). Population dynamic and biological aspects of Scombermorus commerson in the Persian Gulf and Oman Sea (Iranian coastal). IOTC WPNT01-22. 
Devaraj, M. (1983). Maturity, spawning and fecundity of the kingseer, Scomberomorus commerson (Lacepede), in the seas around the Indian Peninsula. Indian J. Fish. 30 (2), 203-230.

Effendi, M. I. (2002). Biologi perikanan (p. 116). Yayasan Dewi Sri, Bogor.

(1997). Biologi perikanan (p.163). Yayasan Pustaka Nusatama (12).

(1979). Metode biologi perikanan (p. 112). Yayasan Dewi Sri, Bogor (8) .

Govender, A., Al-Oufi, H., McIlwain, J.L., \& Claereboudt, M.C. (2005). A per-recruit assessment of the kingfish (Scomberomorus commerson) resource of Oman with an evaluation of the effectiveness of some management regulations. Department of Marine Science and Fisheries. Fisheries Research. 77, 239-247.

Govender, A. (1993). Growth of the king spanish mackerel (Scomberomorus commerson) of the coast of Natal, South Africa from length and age data. Fisheries Research. 20, 63-79

Grandcourt, E., Al Abdessalaam, T. Z., Francis, F., Al Shamsi, A. T., Al Ali, S., Al-Ali, K., Hartmann, S., \& Suwaidi, A. 1. (2005). Assessment of the fishery for kingfish (Kanaad/Khabat), Scomberomorus commerson, in the waters of Abu Dhabi Emirate. Marine environmental research centre. United Emirate Arab, $1-14$.

Jayabalan, N., Lubna Al-Kharusi., Saoud Al Habsi., Shama Zaki., Fatma Al-Kiyumi., \& Dawood Suliman. (2011). An Assesment of Share Stock Fishery of the Kingfish Scomberomorus commerson (Lacepede 1800) in The GCC Water. J.Mar. Biol. Ass. India, 53, 46-57.

Kaymaram, F., Hossainy, S. A., Darvishi, M., Talebzadeh, S.A., \& Sadeghi, M. S. (2010). Reproduction and spawning patterns of the Scomberomorus commersonin the Iranian coastal waters of the Persian Gulf and Oman Sea. Iranian Journal of Fisheries Sciences, 9 (2), 233-244.

Lowe-McConnell R. H. (1991). Ecological Studies in Tropical Fish Communities (p. 400). Australia: Cambridge University Press.

Mackie, M. C., Lewis, P. D., Gaughan, D. J., \& Newman, S. J. (2005). Variability in spawning frequency and reproductive development of the narrow-barred spanish mackerel (Scomberomorus commerson) along the west coast of Australia. Fisheries Buletin, 103, 344-354.
Mackie, M. C., Gaughan, D. J., \& Buckworth, R. C. (2003). Stock Assessment of narrow barred spanish mackerel (Scomberomorus commerson) in Western Australia. Final Report FRDC, 1-242.

Murua, H. \& Kraus, G. (2003). Procedur to Estimate Fecundity of Marine Species in Relation to their Reproductive Strategy. Journal North. Atl. Fisherie Science. 33, 23:32.

Noegroho, T., Hidayat, T., Chodriyah, U., \& Patria, M. P., (2013). Hubungan panjang berat, faktor kondisi, dan kebiasaan makanan ikan tenggiri (Scomberomorus commerson) yang tertangkap di perairan Teluk Kwandang, Laut Sulawesi, dalam Suman et al., Ed. 2013. Status Pemanfaatan Sumberdaya Ikan di Perairan Laut Sulawesi. IPB Press. 53, 1-12.

Noegroho, T., Chodriyah, U., \& Hidayat, T., (2012). Hasil tangkapan, laju tangkap, dan panjang rata-rata tertangkap ikan tenggiri (Scomberomorus commerson) dari kapal pajeko lampu di perairan Kwandang, Laut Sulawesi, dalam Kartamihardja et al., Ed. 2012. Penguatan pengelolaan sumberdaya ikan menuju ekonomi biru industrialisasi perikanan tangkap. Prosiding Seminar Nasional Perikanan Tangkap. 385, 1-9.

Randall, J. E. (1995). Coastal fishes of Oman. University of Hawaii Press, Honolulu Hawaii, (p.1-439)

Rohit, P. \& Abdussamad, E. M. (2013). Fishery, biology and population characteristics of the narrow barred spanish mackerel Scomberomorus commerson exploited in India. IOTC-WPNT03-26.1-6.

Sadeghi, M. S., Kaymaram, F., Jamili, S., Fatemi, M. R., \& Mortazavi, M. S. (2009). Pattern of reproduction and spawning of the Scomberomorus commerson in the coastal water of Iran. Journal of Fisheries and Aquatic Science. 4. (1), 32-40.

Schaefer, M. B. \& Orange, C. J. (1956). Studies on sexual development and spawning of yellowfin tuna (Thunnus albacares) and skipjack (Katsuwonus pelamis) in three areas of the eastern Pacific Ocean by axamination of gonads. Bull.I-ATTC 1 (6), 282-349.

Siddeek, M. S. (1995). Review of Fisheries biology of Scomberomorus and Acanthocybium species in the western Indian Ocean (FAO Area 51). Working Group on Pelagics, 2, 1-32.

Sugiyono. (2004). Statistic non parametric for research (p. 306). CV. Alfabeta, Bandung (6) 
Udupa, K. S. (1986). Statistical method of estimating the size at first maturity in fishes. ICLARM, Metro Manila, Fishbyte, 4 (2), 8-10.
Widodo, A. A., Satria, F., Sadiyah, L., \& Riyanto, J. (2011). Neritic tuna species caught drifting gillnet in Indian Ocean based in Cilacap Indonesia. IOTC-WPNTO121: 1-19. 
Lampiran1. Pembagian tingkat kematangan gonad (Schaefer \& Orange 1956).

Appendix 1. Distribution of gonad maturity stage (Schaefer \& Orange 1956).

Betina/Female

\begin{tabular}{|c|c|c|}
\hline TKG & Kategori & Diskripsi \\
\hline I & $\begin{array}{l}\text { Dara berkembang/ } \\
\text { juvenille/resting } \\
\text { (immature) }\end{array}$ & $\begin{array}{l}\text { Gonad memanjang dan ramping, panjangnya sekitar sepertiga dari rongga } \\
\text { perut, jenis kelamin dapat dilihat dengan kaca pembesar, ovari jernih abu- } \\
\text { abu hingga kemerah-merahan. }\end{array}$ \\
\hline II & $\begin{array}{l}\text { Perkembangan } \\
\text { I/maturing }\end{array}$ & $\begin{array}{l}\text { Gonad membesar tetapi telur tidak dapat dilihat satu per satu dengan mata } \\
\text { biasa, ovari berbentuk bulat telur, berwarna kemerah-merahan dengan } \\
\text { pembuluh kapiler, ovari mengisi sekitar setengah ruang bawah. }\end{array}$ \\
\hline III & $\begin{array}{l}\text { Perkembangan } \\
\mathrm{II} / \text { mature }\end{array}$ & $\begin{array}{l}\text { Gonad membesar dan membengkak, telur mudah dilihat dengan mata biasa, } \\
\text { ovari berwarna orange kemerah-merahan, ovari mengisi } 2 / 3 \text { ruang bawah. }\end{array}$ \\
\hline IV & Bunting/matang/ripe & $\begin{array}{l}\text { Gonad mengisi penuh ruang bawah, ovari telah membesar, telur jernih dan } \\
\text { sudah masak, mudah keluar dari lumen ovari kalau perut ikan ditekan }\end{array}$ \\
\hline V & $\begin{array}{l}\text { Memijah/spawned/ } \\
\text { Spent }\end{array}$ & $\begin{array}{l}\text { Termasuk yang mijah sekarang (salin) dan sebelumnya (post-spawning. } \\
\text { Gonad menyusut memiliki dinding longgar. Ovari sangat besar dan lunak } \\
\text { (karena mijah). Telur matang masih ada yang tertinggal dalam ovari, telur } \\
\text { berwarna jernih. Telur akan keluar dengan sedikit tekanan pada perut. }\end{array}$ \\
\hline \multicolumn{3}{|l|}{ Jantan } \\
\hline$\overline{\text { TKG }}$ & Kategori & Diskripsi \\
\hline I & $\begin{array}{l}\text { Jaka berkembang/ } \\
\text { juvenille/resting } \\
\text { (immature) }\end{array}$ & $\begin{array}{l}\text { Testis sangat halus, pipih seperti pita tetapi jenis kelamin dapat dibedakan } \\
\text { dengan kaca pembesar. Sebagian sperma terdapat dalam saluran pusat. }\end{array}$ \\
\hline II & $\begin{array}{l}\text { Perkembangan } \\
\text { Imaturing }\end{array}$ & $\begin{array}{l}\text { Testis membesar, penampang melintang berbentuk segitiga, berwarna } \\
\text { kemerah-merahan atau mulai putih dengan pembuluh kapiler, kecil dan } \\
\text { padat. }\end{array}$ \\
\hline III & Matang/ripe & $\begin{array}{l}\text { Testis membesar dan membengkak, warna putih agak buram, sperma sedikit } \\
\text { keluar bebas bila di tekan/gonad dipotong, dapat dilihat dengan mata biasa. }\end{array}$ \\
\hline IV & Salin/partly spent & $\begin{array}{l}\text { Testes sangat membesar, warna putih buram ada bintik-bintik merah, sperma } \\
\text { mudah keluar kalau perut ikan ditekan sedikit atau saat gonad dipotong. }\end{array}$ \\
\hline $\mathrm{V}$ & Pulih salin/spent & $\begin{array}{l}\text { Testis lunak, gelap kemerahan, dinding gonad lembek dan ada pembuluh } \\
\text { darah. }\end{array}$ \\
\hline
\end{tabular}


Lampiran 2. Distribusi frekuensi panjang ikan tenggiri dari perairan Teluk Kwandang Appendix 2. Length frequency distribution of Spanish mackerel from Kwandang Bay water

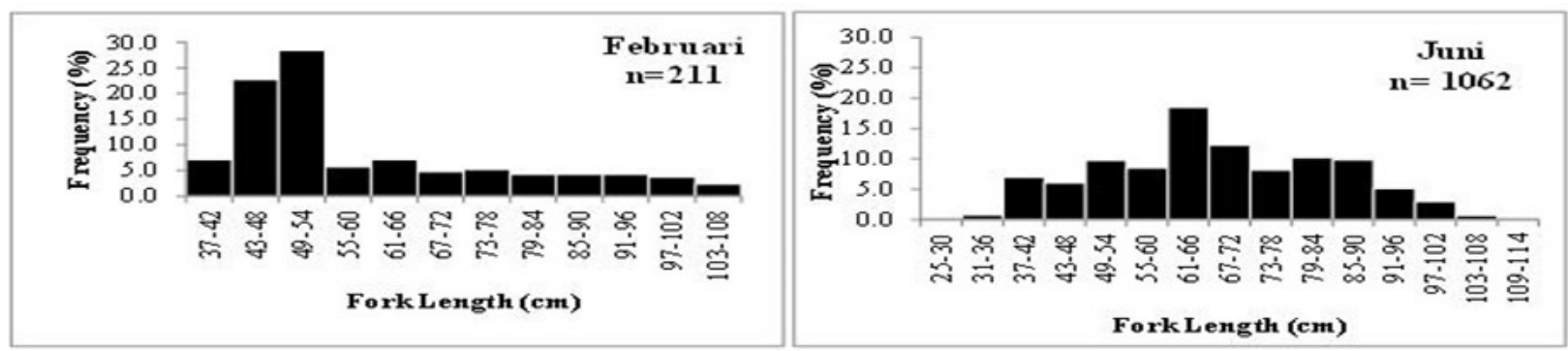

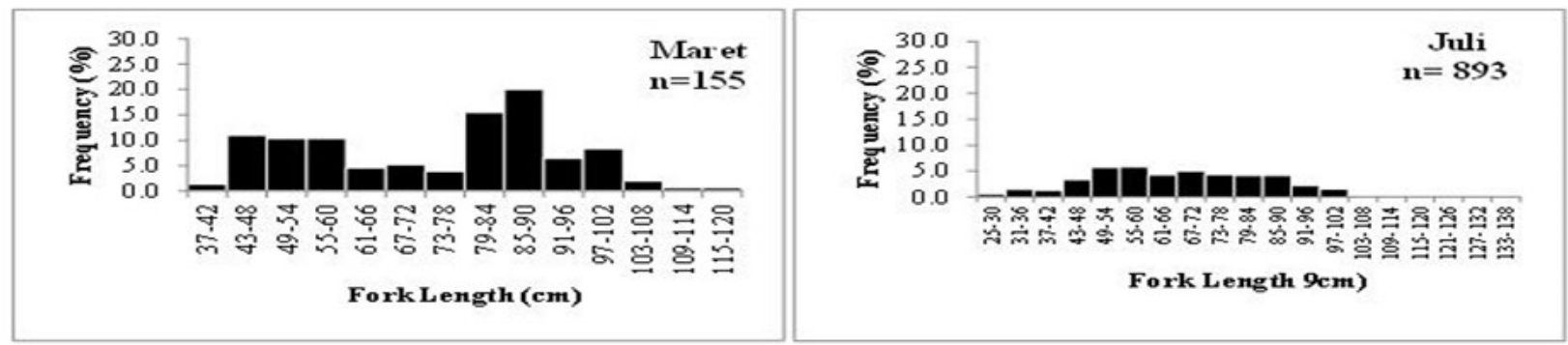

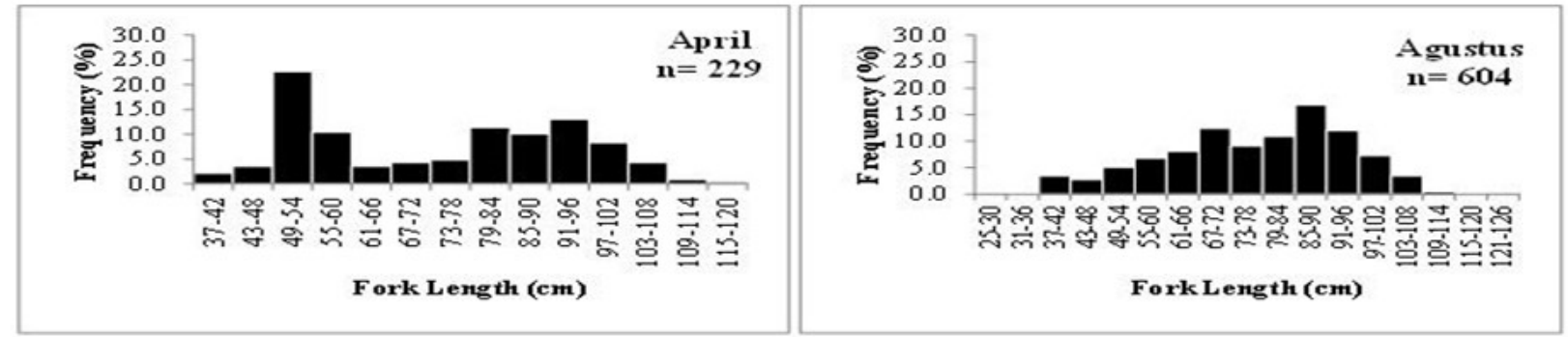

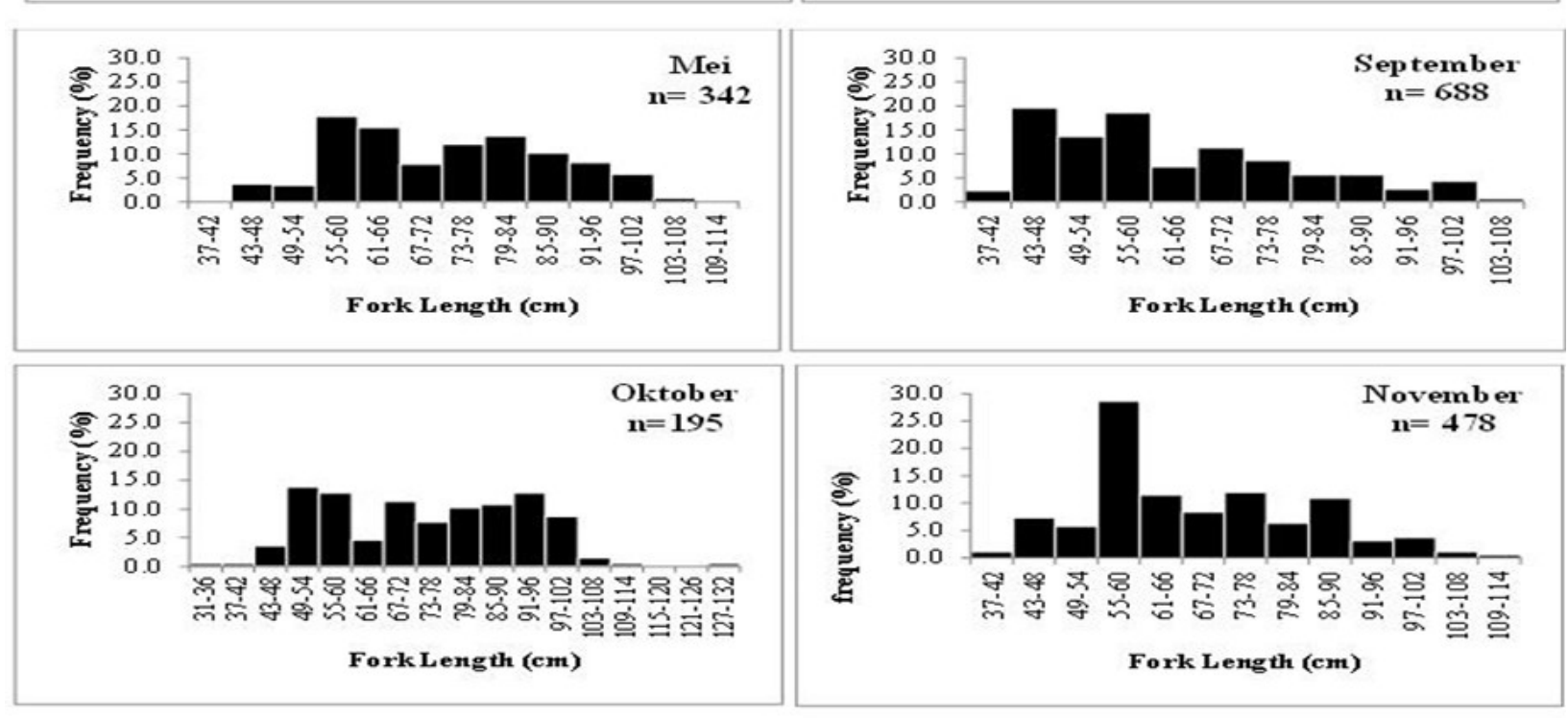

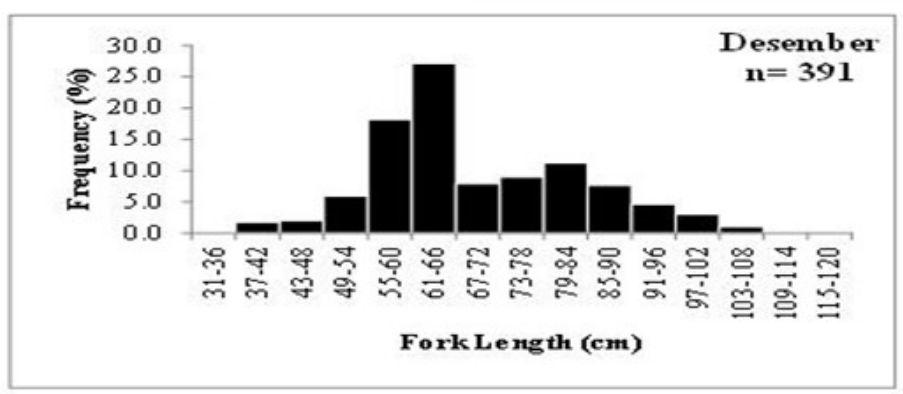


Lampiran 3. Uji chi square dari nisbah kelamin ikan tenggiri Appendix 3. Chi square test from sex ratio of spanish mackerel

\begin{tabular}{|c|c|c|c|c|c|}
\hline \multirow{2}{*}{$\begin{array}{l}\text { Bulan/ } \\
\text { Month }\end{array}$} & \multicolumn{2}{|c|}{$\begin{array}{l}\text { Frek. Observasi/ Observation Freq. } \\
\text { (f0) }\end{array}$} & \multirow{2}{*}{$\begin{array}{l}\text { Frek. Harapan/ } \\
\text { Expected Freq. (fn) }\end{array}$} & \multicolumn{2}{|c|}{$\mathrm{X}^{2}$ Hitung/ $\mathrm{X}^{2}$ Calculate } \\
\hline & Betina/ Female & Jantan/ Male & & $\begin{array}{l}\text { Betina/ } \\
\text { Female }\end{array}$ & $\begin{array}{l}\text { Jantan/ } \\
\text { Male }\end{array}$ \\
\hline Feb & 11 & 13 & 12 & 0,083 & 0,083 \\
\hline Mar & 12 & 24 & 18 & 2,000 & 2,000 \\
\hline Apr & 47 & 39 & 43 & 0,372 & 0,372 \\
\hline May & 6 & 10 & 8 & 0,500 & 0,500 \\
\hline Jun & 15 & 36 & 25.5 & 4,324 & 4,324 \\
\hline Jul & 23 & 10 & 16.5 & 2,561 & 2,561 \\
\hline Aug & 24 & 23 & 23.5 & 0,011 & 0,011 \\
\hline Sep & 6 & 9 & 7.5 & 0,300 & 0,300 \\
\hline Oct & 8 & 11 & 9.5 & 0,237 & 0,237 \\
\hline Nov & 32 & 32 & 32 & 0,000 & 0,000 \\
\hline \multirow[t]{3}{*}{ Dec } & 12 & 10 & 11 & 0,091 & 0,091 \\
\hline & & & & 10,478 & 10,478 \\
\hline & & & $\mathrm{X}^{2}$ Hitung/ $\mathrm{X}^{2}$ Calculate & \multicolumn{2}{|c|}{20,956} \\
\hline
\end{tabular}

$\mathrm{X}^{2}$ hitung $=20,956$

$\mathrm{X}^{2} 0,05(1)(\mathrm{n}-1)$

$X^{2} 0,05(10)=18,307$

$\mathrm{X}^{2}$ hitung $>\mathrm{X}^{2}$ tabel, terima $\mathrm{H} 1$ dan tolak $\mathrm{H} 0$, terdapat perbedaan yang nyata antara jumlah ikan tenggiri betina dan jantan. 